\title{
Implementing Public Sector Accruals in OECD Member States: Major Issues and Challenges

\author{
P Adhikari and L Nesbakk
}

\begin{abstract}
Drawing on extended new institutional theory, this paper has striven to make heard the voices of accountants, budget officers, and policy makers involved in implementing public sector accruals in different OECD member states. Such voices of the organisational actors and the challenges that they are encountering in the process of implementing accrual accounting and budgeting in their specific settings are missing in the existing public sector accruals literature. The empirical findings of the study demonstrate that the political and technical ambiguities in implementing public sector accruals across countries are much broader than outlined in the academic work and presented in the reports and studies of the proponents. Such challenges, when cascaded down to the organisational level, have brought about vast uncertainty and confusion amongst most of the budget and treasury officers who deal with public sector accruals in their specific jurisdictions, threatening the legitimacy at the organisational level. More communication and collaboration amongst the actors at institutional, organisationalfield and organisational levels are therefore needed to build a coherent body of knowledge in facilitating public sector accruals reforms across countries.
\end{abstract}

Keywords: Accrual accounting, Institutional theory, IPSASs, OECD, Public sector.

\section{Introduction}

The aim of this paper is to explore the major challenges involved in implementing public sector accruals in Organisation for Economic Co-operation and Development (OECD) member countries. We look at the concerns of key organisational actors of OECD member states, the majority of whom are senior accountants from treasuries and budget officers, as well as policy makers from ministries or governmental bodies directly involved in developing or implementing accrual accounting and budgeting reforms in their respective jurisdictions. The OECD represents a propitious research setting of accrual accounting experiences since the vast majority of its members are developed countries, EU members and the major 
adopters of accrual accounting and budgeting at a global level (Blöndal, 2003). The organisation is perhaps the best representative of a global trend in public sector accruals.

Implementing accrual accounting in OECD member states has become a key part of realising public sector financial reforms, which are collectively referred to as New Public Management (NPM) and New Public Financial Management (NPFM) reforms (Hood, 1995; Guthrie, Olson, \& Humphrey, 1999). As part of improving public sector governance (Almquist, Grossi, van Helden, \& Reichard, 2013), the OECD has advocated the adoption of accrual accounting for its member countries (Blöndal, 2003, 2004). Member states' attempts at replacing their cash accounting with accrual accounting are considered to be inevitable, particularly in the evolving sovereign debt crisis. Such efforts are hailed as major achievements in managing public expenditures more effectively and efficiently (Lapsley, Mussari, \& Paulsson, 2009; Pollanen \& Loiselle-Lapointe, 2012). Similar assertions relating to the supremacy of accrual accounting to budgetary accounting in terms of improving transparency in resource allocation, identifying full costs of governments' activities, and engendering high quality statistics, i.e. the Government Finance Statistics (GFS) and the European System of Accounts (ESA), which are crucial for fiscal and spending decisions, have been made by international organisations [e.g. the International Monetary Fund (IMF) and the World Bank], regional policy makers [e.g. the European Commission (EC)], international accounting and auditing standards setters [e.g. the International Federation of Accountants (IFAC) and the EUROSTAT], and professional accounting associations and accounting firms [e.g. the Federation of European Accountants (FEE), the Chartered Institute of Public Finance \& Accountancy (CIPFA), Ernst \& Young and PricewaterhouseCoopers $(\mathrm{PwC})]$, all of which are considered to be major proponents of public sector accruals (see e.g. IFAC, 2011; PwC, 2013; FEE, 2007).

Despite this support, many of these proponents have also cautioned the implementation of accrual accounting in the public sector, given its technical ambiguities and the amount of resources and expertise that the countries should make available to address them (IFAC, 2011; FEE, 2007). For instance, professional associations, standards setters and firms of auditors or accountants have expressed several reservations with regard to the adoption of accrual accounting and International Public Sector Accounting Standards (IPSASs) by the EU member states (European Commission, 2012). Within the academic community, the move towards accrual accounting has been a debated reform trajectory (Carlin, 2005). While some academics are apparently convinced of the benefits of accrual accounting (see e.g 
Annesi-Pessina \& Steccolini, 2007; Likierman, 2003; Ball, 2012; Bergmann, 2012; Caperchione, 2006; Lüder \& Jones, 2003), others have raised concerns over the pertinence of business-like accrual accounting in public entities, which have different objectives and contexts (see e.g. Guthrie, 1998; Mellett, 2002; Carlin, 2005; Ezzamel, Hyndman, Johnsen, \& Lapsley, 2014; Monsen, 2002; Becker, Jagalla, \& Skærbæk, 2014; Connolly \& Hyndman, 2006). The latter group is of the view that the implementation of accrual accounting is driven more by legitimacy than efficiency reasons and that the benefits of accrual accounting are overstated.

The arguments for and against the implementation of public sector accruals - uttered by international organisations, policy makers, standards setters, professional accountants and academics-are claimed to be normative and lacking empirical evidence (Jagalla, Becker, \& Weber, 2011; Lapsley, Mussari, \& Paulsson, 2009). For example, there is apparently a gap between what is normatively expected from accrual accounting and what has been achieved in its implementation at different organisational levels in practice (Guthrie, 1998). This is evident in countries such as Australia and the UK - the early adopters of accrual accounting and budgeting - given the time and resources consumed in the implementation (Guthrie, 1998; Connolly \& Hyndman, 2006; Hyndman \& Connolly, 2011). Missing from the public sector accrual literature, however, are the voices of actors at the organisational level, primarily government accountants, budget officers and policy makers, who are actually involved in implementing accrual accounting. Questions that are yet to be answered in the public sector accrual literature include how such organisational actors are advancing public sector accruals reforms in their specific settings, the strategies and mechanisms they are deploying and the specific challenges that they are encountering in the implementation process.

This paper strives to fill this knowledge gap in the public sector accrual literature. We seeks to make heard the voices of accountants, budget officers, and policy makers involved in implementing various aspects of accrual accounting and budgeting in different OECD member states. This is approached through the extended version of neo-institutional theory, also referred to as new institutionalism (Carruthers, 1995; DiMaggio \& Powell, 1983), particularly the version that acknowledges the role of intra-organisational actors in the institutionalisation process. Some aspects of a framework proposed by Dillard, Rigsby, \& Goodman (2004) have been adopted. This angle allows us to delineate how the public sector 
accrual ideas and practices cascade down through different levels, in particular the economic and political level (i.e. the OECD), the organisational-field level (i.e. OECD member states), and the organisational level (i.e. actors in different OECD member states), prior to their adoption in particular contexts.

The remainder of the paper is organised as follows. The ideas of new institutionalism, which provide a sensitising lens for this study, are presented in Section 2. The research method is outlined thereafter. Section 4 presents the views and experiences of OECD member states with regard to public sector accruals and the challenges they have encountered in implementing different elements of accrual accounting, budgeting and IPSASs in their specific contexts. The final section analyses the implementation of public sector accruals in the member states in the light of the theory, and offers some concluding remarks.

\section{Theoretical framework: extended new institutionalism}

Public sector accounting scholars have striven to theorise accounting changes using varied sociological approaches (see e.g. Jacobs, 2012; Van Helden, Johnsen, \& Vakkuri, 2008; Goddard, 2010). For instance, several pieces of research have drawn on the ideas of actor network theory, in particular the concept of translation (see e.g. Latour, 1987; Callon, 1986) to analyse how accounting changes (see e.g. Justensen \& Mouritsen, 2011) and the ways in which innovations, through a network of human and non-human allies, have taken place in the health care sector (Preston, Cooper, \& Coombs, 1992; Chua, 1995; Lowe, 2000) as well as in other public sector settings (Christenen \& Skærbæk, 2007, 2010; Lukka \& Vinnari, 2014). The widespread adoption of accrual accounting in the public sector has nevertheless been predominantly associated with the ideas of new institutionalism (Modell, 2013; Jacobs, 2012). Many theoretical perspectives have failed to explain accounting changes with reference to external variables/environment, which have increasingly become dominant in regulating accounting practices at a global level. Implicit in neo-institutional theory (see e.g. Meyer \& Rowan, 1977; DiMaggio \& Powell, 1983) is the role of external organisations/institutions, for instance, the IFAC, the European Commission, and the OECD amongst others, in disseminating public sector accounting reforms (Jacobs, 2012). The extent

public sector accounting literature has therefore drawn on neo-institutional theory to investigate how similar reform ideas (i.e. accrual accounting and the IPSASs) have been diffused across countries, although there are significant variations in reform outcomes, i.e. 
practice variations (Ahn, Jacobs, Lim, \& Moon, 2014; Carpenter \& Feroz, 2001; Ezzamel, Hyndman, Johnsen, Lapsley, \& Pallot, 2007; Pollanen \& Loiselle-Lapointe, 2012; Hyndman \& Connolly, 2011; Oulasvirta, 2014).

The ideas of new institutionalism have primarily drawn on the notions of "legitimacy" and "isomorphism" (Meyer \& Rowan, 1977; DiMaggio \& Powell, 1983). It is stated that organisations tend to conform to socially accepted norms and structures as part of their legitimacy-seeking behaviour, and in the process become isomorphic. DiMaggio \& Powell (1983) mention three pressures/mechanisms contributing to organisational isomorphism, i.e. coercive, mimetic, and normative. While the coercive mechanism, especially in the public sector, has been linked to state intervention and pressure from resource providers, the normative mechanism has been seen as an outcome of professionalisation (e.g. through the influence of consultants, scholars or other esteemed professionals). The mimetic mechanism is concerned with emulating the ubiquitous practices in the field which have a tag of being successful and modern. A stream of public sector literature draws on these three mechanisms to explain how the adoption of accrual accounting has become an integral element of legitimacy-seeking behaviour, thereby illuminating the case of accounting choices within organisations (Carpenter \& Feroz, 2001; Adhikari, Kuruppu, \& Matilal, 2013; Irvine, 2008; Ball \& Craig, 2010). Ensuring legitimacy has been indispensable for public sector entities, not only to avoid critical questions regarding their activities but also to portray their image as modern and rational organisations in their operating contexts. However, Hyndman \& Connolly (2011: 38) have differentiated between organisations/countries in terms of their concerns over legitimacy. They argue that the early adopters of accrual accounting in the public sector, i.e. New Zealand, Australia and the UK, were to a large extent motivated by technical economy efficiency gains, but that the later adopters were more concerned with legitimacy and involved in "mindless imitation fuelled by anxiety-driven pressures to conform".

Ahn, Jacobs, Lim, \& Moon (2014) argue that recent new-institutionalism-based studies in the public sector have given more attention to unfolding heterogeneities in reforms than to organisational isomorphism. Public sector entities have increasingly becoming divergent in the process of implementing reforms (Modell, 2013; Jones, Lande, Lüder, \& Portal, 2013). One way to depict such heterogeneities in reforms has been to recognise the internal dynamics and the role of internal actors, at different organisational levels, in the reform 
process (Ezzamel, Hyndman, Johnsen, Lapsley, \& Pallot, 2007). In fact, this lack of focus on human agents and their actions within organisations has been a key weakness of the earlier institutional-based studies (Dillard, Rigsby, \& Goodman, 2004; Tsamenyi, Cullen, \& Gonzalez, 2006). Recent studies drawing on new institutionalism have therefore acknowledged that the support and competence of organisational actors (for instance, bureaucrats and accountants) can play a vital role in the institutionalisation/deinstitutionalisation of public sector accounting reforms in a specific context (Hyndman \& Connolly, 2011; Pollanen \& Loiselle-Lapointe, 2012; Adhikari, Kuruppu, \& Matilal, 2013). Claims have been made that it is due to the involvement of actors at different levels that organisations respond differently to similar reforms, leading to diverse outcomes.

Studies have striven to address this drawback of neo-institutional theory and to identify the varying effects of organisational actors/individuals in the institutionalisation process, not least by combining institutional theory with other theories, for instance, the work of Bourdieu (Ahn, Jacobs, Lim, \& Moon, 2014). Dillard, Rigsby, \& Goodman (2004), for instance, applied a three-layer organisational structure framework to unfold the issues of power, structures, and duality in the institutionalisation process. We draw on this notion of threelayer organisational structure framework (see e.g. Dillard, Rigsby, \& Goodman, 2004), but apply it differently. In our study, the framework is used to unravel how the ideas and practices of public sector accruals have cascaded down from the OECD to member states, and then on to organisational actors in individual member states. At the macro level of our structure (i.e. the economic and political level) there are policy makers (i.e. the OECD and the European Commission), accounting standards setters (i.e. the IFAC's International Public Sector Accounting Standards Board (IPSASB) and the International Accounting Standards Board (IASB), and international organisations (i.e. the IMF and the Eurostat); actors/organisations propagating public sector accruals in the member states and providing guidance on its implementation. We have divided the micro level into two categories, the organisational-field level and organisational level. The organisational-field level consists of member states. Lower down is the organisational level, the term we have used to refer to senior accountants, budget officers and policy makers; i.e. the attendees of the OECD accrual accounting symposiums, who are involved in implementing accrual accounting and budgeting in their contexts. It is at this level that the ideas of public sector accruals tend to translate into actual practices and become institutionalised. We argue that the use of this 
structure will allow us to study the response of most of the OECD member states to public sector accruals, and the challenges that the organisational actors at different hierarchies are encountering in implementing accrual accounting and budgeting in their specific jurisdictions.

\section{Research setting, data collection and analysis}

\subsection{An overview of the annual public sector accruals symposium}

The research site of our study is the annual OECD public sector accruals symposiums. As part of its attempt at encouraging member states to adopt accrual accounting and budgeting, the OECD has been organising an annual accrual accounting symposium since 2001 (see Appendix A for the members list). The symposium is meant to bring about the challenges that the member countries have encountered in making a transition towards and in implementing public sector accruals (Blöndal, 2003). Some non-member countries, which have either adopted or are in the process of adopting accrual accounting, are also invited to participate in the symposiums and are provided with the opportunity to share their experiences with the member states. Our review of the presentation slides uploaded on the OECD website and the list of participants provided by the OECD shows that the majority of the attendees in the symposiums are treasury officers, senior accountants, budget officers and policy makers involved either directly or indirectly in implementing accrual accounting and budgeting in their respective countries. Along with country representatives, there are representatives from the standards setters, regulators, and international organisations such as the European Commission, the IASB, the IPSASB, the IMF, the EUROSTAT, and the World Bank, amongst others, attending the symposiums on a regular basis and updating the member states with their ongoing activities and projects. In this regard, the annual symposiums have provided a forum for accounting practitioners, budget officers, policy makers and standard setters in which they gather annually to discuss various aspects of public sector accruals. We have witnessed that many issues relating to public sector accruals discussed in earlier symposiums, for instance, conceptual framework, service concession arrangements and financial instruments, had later been converted into an exposure draft and subsequently to a standard. In addition, we have also noticed that some of the participants who had represented their countries (e.g. Australia and New Zealand) in one or more symposiums had later been nominated in the Board of the IPSASB. This is some of the evidence demonstrating the 
influence that the symposiums have in developing and promoting public sector accruals at a global level.

\subsection{Data collection}

We adopted a triangular approach to data collection, encompassing document analysis, observation of the annual accrual accounting symposiums, and informal discussions with the attendees of the symposiums. At the outset we reviewed documents, mainly the presentation slides and the reports presented by the participants in the symposiums. Our aim in reviewing these documents was not only to grasp insights into the emerging accrual accounting reform issues in the member states, but also to identify those topics that had repeatedly been brought forth for discussion in the subsequent symposiums. This helped us to highlight the areas/topics within public sector accruals that are of concern to the representatives of the member states, international organisations and standard setters.

Next, we attended the annual symposiums consistently from 2008 to 2011 and observed the discussions that took place in those four symposiums. The symposium is normally organised in the first week of March each year and lasts for two days. We had permission from the head of the OECD budgeting and public expenditure division to observe the sessions and attend the social events. However, we were prohibited to conduct formal interviews with the participants. We took notes in each session, elaborating on the issues embedded in the presentation slides, handouts and reports that were distributed to the participants during the meetings and later made available on the website.

Our other approach to gathering data was to talk informally with the delegates during the coffee and lunch breaks as well as at the reception, which is usually held on the first day of the symposium. Altogether we talked (both jointly and individually) to more than 35 delegates representing the member states, standard setters and international organisations during our four years of observation. The duration of these conversations ranged from 10 to 45 minutes, depending on the settings (i.e. whether it was before or after the sessions officially started or ended, or took place during a coffee break, reception, lunch or dinner). We attempted to recall and transcribe the major issues immediately after each conversation. Our aim during the conversations had been to incorporate the views of all types of actors and countries represented in the symposiums. The OECD has, on the basis of financial statements 
prepared by the member states, identified four stages in the development of accrual accounting, i.e. full accrual basis, modified accrual basis, cash basis with supplementary accrual data, and cash basis (see e.g. Blöndal, 2003; Carlin, 2005), and has placed the member states in one of these four categories. We selected representatives from each category for a discussion and asked them about the ongoing development in public sector accruals in their jurisdictions, their future agenda and plans, and the challenges they had faced and achievements made in facilitating public sector accruals reforms. Although the representatives had divided opinions based on the stages their countries were in implementing changes, we experienced that the opinions of the attendees representing a particular group had remained more or less stable during our observation periods. While the countries of the full accrual basis category, for instance Australia and New Zealand, had consistently remained strong supporters of public sector accruals, other countries seemed to not be fully convinced by the merits of the accrual basis in that they had adopted only some degree/elements of accruals, and mainly for financial reporting.

We were aware of the fact that the situation might have changed in some countries since our last observation, which took place in 2011. To get updated information of the progress made by the member states in embracing public sector accruals, we reviewed the slides, documents, and annotated agenda presented in the subsequent symposiums by accessing the OECD website. There has been an increase in recent years in the number of member states adopting some elements of accruals in their financial reporting. However, we observed that the number of countries that have adopted full accruals both for reporting and budgeting has remained constant in this period. We also noticed that that the topics/issues incorporated on the agenda for discussion have to a large extent remained stable in the last few years. We have reasoned that this is an indicator that the challenges intertied to public sector accruals are yet to be resolved, and that the progresses made in tackling these issues have been slow.

\subsection{Data analysis}

We began our data analysis by separating issues in public sector accruals that had been discussed repeatedly in the OECD symposiums. Overall we identified three themes/issues that had consistently emerged in the discussions in the symposiums for more than three years: "the implementation of accrual accounting, "the significance of accrual budgeting" and "the 
applicability of IPSASs". The data representing each theme were then clustered and attempts were made to establish links between these themes so as to create narratives.

Given the fact that our approach to data collection was informal talks, we decided to maintain the anonymity of the countries. To represent the views of most of the member states and to compare their opinions, we followed Hood (1995) by grouping the member states into three categories, i.e. high-intensity accrual adopters, medium-intensity accrual adopters and low-intensity accrual adopters (Appendix B) (see also Hyndman \& Connolly, 2011; Guthrie, Olson, \& Humphrey, 1999). In addition, we added a new category, i.e. new accrual adopters, to represent non-members who have recently embarked on accrual accounting reforms. Our grouping also corresponds to the OECD attempt's at dividing its member states based on their stages in adopting public sector accruals As stated in the extant literature (Grossi \& Soverchia, 2011; Benito, Brusca, \& Montesinos, 2007; Pina \& Torres, 2003; Lüder \& Jones, 2003; Pina, Torres, \& Yetano, 2009; Christiaens, Vanhee, Manes-Ross, Aversano, \& Cauwenberge, 2014), classifying countries based on their government accounting systems is not an easy task given the diversity in their operating context and the varied objectives of government accounting across countries. We argue that the sole purpose of our classification was to bring about the views of most member states who were at different states in reforming their accounting and budgeting at central government levels. For instance, the high-intensity group consists of countries such as Australia, the UK, and New Zealand, which have, according to Blöndal (2015) adopted full accruals for both financial reporting and appropriations. While the medium-intensity group represents the countries which have adopted some elements of accruals at their central government levels either for reporting and budgeting or for both, the low-intensity adopters are those who are predominately adhering to the cash basis at the central level (few of them however provide supplementary accrual accounting information) (see Appendix B for details). Given the fact that our categories are based on the development at central government levels, they may vary if we consider the adoption of accrual accounting in agencies and at local levels.

Regarding the limitations of the study, one limitation is that it does not cover all the topics that were discussed in the symposiums. For example, in each symposium there were some emerging issues; we noticed that most of these issues, such as social accounting and the global financial crisis either petered out over time or were replaced with other similar issues. We also excluded the updates of the IPSASB and the IASB, and the reports of the IMF and 
Eurostat because they were predominantly oriented toward the future and were general rather than addressing country-specific issues. Another limitation of our study is that we were prohibited from making formalised interviews. However, we believe this disadvantage is less severe when seen in relation to the total amount of data we collected through our triangulation approach over the four consecutive years. Finally, we believe that being able to collect data through observations was particularly important as this enabled us to capture the practitioners' viewpoints as they naturally emerged through debate, rather than having the issue artificially being introduced such as in a formal interview setting.

\section{Empirical section}

Drawing on our informal discussions, the document search and observation of the OECD public sector accruals symposiums, we have identified three main areas that the policy makers, budget and account officers, and treasurers of the OECD member states have perceived as major challenges in implementing public sector accruals in their specific contexts; "the implementation of accrual accounting, "the significance of accrual budgeting" and "the applicability of IPSASs".

\subsection{The implementation of accrual accounting}

The OECD has considered the accrual basis of accounting an important component of its governance reforms (Blöndal, 2003). It has become an active player in the promotion and dissemination of public sector accruals not least within its member states but at a global level. For instance, the OECD is one of the observers of the IPSASB and has recently, together with the World Bank and the IMF, chaired a review group created to purpose future governance and oversight arrangements for the IPSASB (IPSASB, 2014). It has also liaised with the European Commission, the IMF, the International Organisation of Supreme Audit Institutions (INTOSAI) and the big four auditing firms, amongst others, to facilitate research in areas such as the harmonisation of public sector accounting, the promotion of good practices in accounting and auditing, and governance reforms of the IPSASB (IMF, 2003; IPSASB, 2014). That the European Commission has announced the development of European Public Sector Accounting Standards (EPSASs) and the fact that more than half of the member countries of the OECD come from the EU, means that the organisation may have even a greater impact in deciding on public sector accruals related issues in the future. 
In his presentation at the $15^{\text {th }}$ annual symposium, Blöndal (2015) states that 25 out of the 34 OECD member states have now adopted either full or some elements of accruals in full in their financial reporting. Full accruals indicate that the member countries have been preparing consolidated statements for "Whole of Government Accounts" (WGA), although the controlling entities incorporated in such accounts vary amongst countries (OECD, 2013). We noticed during our observations and informal talks that the institutional pressures for the OECD and EU member states to adopt public sector accruals have significantly increased over the last few years. Organisations such as the OECD, the EU and the IFAC, a key player at the economic and political level, are of the view that the continuation of the outdated cash accounting and budgeting in this era of austerity would inevitably lead to dire consequences for the long-term sustainability of the member states (see also Ball, 2012; Ball \& Pflugrath, 2012). These organisations, together with the global accounting firms such as PwC (see e.g. PwC, 2013), have moved beyond simply recommending accrual accounting and budgeting towards addressing issues which they have perceived to be a major challenge to their implementation; for instance preparing WGA, developing and approving a conceptual framework, and projecting long-term sustainability, to name but a few. Albeit the adoption of public sector accruals is still voluntary, the institutional pressures being exerted by these organisations and other proponents for their adoption have increasingly resembled a characteristic of coercion (DiMaggio \& Powell, 1983). This was also evident in the following statement made by a Technical Director of the European Commission at the 11th accrual symposium:

"We require all candidates for entry into the EU to adopt an accrual basis of accounting. [Otherwise] how is it possible to demonstrate the impact of austerities on a government's cash flows, social benefits, and fiscal sustainability?"

Despite such institutional pressures, we observed that the implementation of accrual accounting has remained both politically and technically a challenging endeavor in the majority of the OECD member states.

\subsubsection{Political challenges}

The public finance system in many central European countries has been different to the Anglo-Saxon tradition given the centralisation of power over the budget (Pina, Torres, \& Yetano, 2009). On this basis it has been predicated that only Anglo-Saxon countries and 
those with Western minister-style parliaments are better equipped to implement reforms such as accrual accounting, which requires, amongst other things, the delegation of power to different government units (Newberry, 2015). The fact that the legislature parliament has already delegated financial powers to the executive government means that reforms that require power to be delegated may not be considered a significant transformation in such countries. Treasuries and finance ministries have therefore emerged as the key drivers of public sector accruals in Anglo-Saxon countries, and this political backing to instigate reforms has allowed the bureaucrats in these countries to develop a detailed implementation plan for reforms without giving much attention to the costs. A Chief Account Advisor at the Treasury of an Anglo-Saxon country (a high-intensity adopter) at the $8^{\text {th }}$ symposium remarked:

"We had a clear mandate and political backing for accrual accounting reforms. We therefore did not think much about the costs of transition. We adopted a phased approach, i.e. moving on by demonstrating achievements and building confidence on accruals. We also used 'dry runs' to resolve the issues that remained contentious, for instance, identifying public entities".

Such was not the case however, in the majority of medium and slow-intensity adopters of public sector accruals. During our informal discussions, the representatives of many low and medium-intensity adopters stated that the politicians in their countries had been reluctant to delegate their inherent financial power to agencies. They had also raised concerns over costrelated issues and questioned the relevance of public sector accruals in their jurisdictions. That many European politicians are reticent towards accrual accounting given the costs incurred in their implementation is evident in the bulk of academic work (Caperrchione, Salvatori \& Benghi, 2014; Brusca, Montesinos, \& Chow, 2013). It is worth mentioning that accounting in some OECD member states, primarily the German-speaking countries and Norway, had traditionally been more than just recoding cash receipts and payments. These countries had adhered to an advanced budgetary accounting, the so-called 'cameralistic accounting' (see e.g. Monsen, 2002, 2008), which had a particular focus on money management, budgetary control and payment control. The system allowed the governments to record and report events that occurred in different budgetary stages and not the cash receipts and payments, which are considered to be the last stage in the budget process. Monsen (2008) argues that a developed version of cameral accounting could provide government entities with the same type of information which the accrual basis of accounting was meant for. This 
has also been envisaged as a reason why some OECD member states, for instance, Germany and Norway tend to leave the traditional budget structure unchanged rather than pursing expensive accrual accounting reforms (Jones, Lande, Luder, \& Portal, 2013). Portal, Lande, Jones, \& Lüder, (2012) state that some central European countries have retained their traditional budget accounting as a system of parliamentary appropriations, even if they have adopted accrual-based financial reporting reforms.

Costs related to accrual accounting transition have also drawn the attention of international organisations and professional accounting firms (PwC, 2013; IFAC, 2011). For instance, in its report, the European Commission (2013) has assumed that the costs of moving away from a cash-based accounting system to an accruals-based accounting system for the central government alone in a medium-sized member could reach up to EUR 50 million given the expense of putting into place the new standards, the associated IT systems, and appropriate training and education. In the same report, it is mentioned that France spent in excess of EUR 1,500 million on articulating accrual accounting and budgeting reforms over the last decade. During our informal talks, the representatives of low and medium-intensity adopters mentioned that they had to spend a lot of time elucidating the politicians and parliamentarians as to the importance of accrual accounting, and how it would help improve transparency and accountability in public finance. In some countries the budget and treasury officers were even forced to revise and alter their transition plan towards accruals. A Senior Accountant at the Department of Treasury of one medium-intensity adopter shared his experienced at the $8^{\text {th }}$ symposium:

"To satisfy the politicians and parliamentarians, we agreed to facilitate the reforms a bit easier, i.e. [we proposed a] cash budget with some accruals modification and accrual accounting for reporting at the federal level. These efforts helped a lot - they approved both the transition plan and the costs."

The new accrual adopters, many of which are emerging countries, are apparently prone to underestimate the transition costs of public sector accruals. As stated by Brusca, Montesinos, \& Chow (2013), there is a tendency amongst many countries, in particular emerging countries to mimic the supposedly best accounting practices adopted by developed countries and international organisations. As part of reflecting the modernity (DiMaggio \& Powell, 1983), many emerging countries (new accrual adopters) had adopted a big-bang approach to 
accruals, i.e. adopting full accruals both for financial reporting and appropriations at all administrative levels (Ernst \& Young, 2012). However, given the costs incurred in the transition process, some of these countries had been forced to move back and adopt a step-bystep approach to reforms. A Director from a Treasury Bureau of the Ministry of Strategy and Finance representing an Asian country (a new accrual adopter) remarked on the step-by-step approach during the $11^{\text {th }}$ accrual symposium:

"We were so eager to follow the reform paths pursued by the Anglo-Saxon countries. In 2010 we had to appoint and dispatch 70 CPAs to support the financial statements of our line ministries. We spent so much money on trainings and other preparatory activities in the field. We changed our big-bang approach later and decided to start the reforms from the ministries."

During our observations and informal discussions, representatives of many member states also raised concerns over the costs incurred in creating awareness of the merits of accrual accounting to other users than the politicians, e.g. the media and civil servants. In many countries, the budget and treasury officers had encountered significant challenges in convincing the press and public of the need for public sector accruals in discharging governments' accountability. The US Department of the Treasury (2010 \& 2014) has, for instance, since the last decade been preparing a simplified version of financial statements for the citizens and press so as to elucidate them as to the financial health and long-term sustainability of the federal government. Accounting practitioners and standard setting institutions have envisaged the prevailing mismatch between accounting practices and the accounting education offered at higher education institutions as a major cause undermining users'/citizens capacity to apply accrual information. The following statement by a Technical Director of one standard setting institution during the $11^{\text {th }}$ symposium illustrated this:

"People do not have the proper education to tackle our work, so the question then is whether we need to adjust our definitions to what is being taught in our schools."

As stated by Lombrano \& Zanin (2013), this is not surprising given the fact that the citizens are more interested in assessing the quality of public services rather than the information supplied by the financial statements. The proponents of accrual accounting are of the view that, albeit the visible costs of transition to accruals may appear large in absolute terms, they are relatively small when compared to the share of public expenditure in countries' GDP (CIPFA, 2012). Heald \& Georgios (2011), for instance, state that public 
sector spending accounts for more than $40 \%$ per cent of the UK's GDP. It is stated that the costs of poor decision-making resulting from incomplete cash information are much higher than the transition costs for accrual accounting. In its report, CIPFA (2012) states that many countries that are in pursuit of cash accounting have been developing additional systems and procedures by incurring substantial costs so as to manage their assets, liabilities, programmes and commitments.

\subsubsection{Technical challenges}

Several technical difficulties have been envisaged in implementing accrual accounting in the member states, in particular amongst the low and medium-intensity adopters. The public sector consists of a large number of assets and liabilities, for instance, heritage assets, military assets, infrastructure assets, and social insurance programs, which do not exist in the private sector (Blöndal, 2003, 2004). Of the technical challenges, a key challenge has been to decide whether there is a need to abandon the historical value used for the measurement of these assets and liabilities and to replace it with alternative valuation models such as market value, fair value and replacement cost. Replacing historical value with fair value has however been a challenging endeavour for many member states given the characteristics of such assets and obligations which seldom have any liquid and traceable markets. Many attendees representing the medium and low-intensity adopters were of the view that they would not indulge themselves in the market value discussion as it was not relevant to them. This was evident in the following comment made by a Deputy Director for Budget and Financial Planning at the Ministry of Finance of one medium-intensity-adopter at the $8^{\text {th }}$ accrual symposium:

"We have no intention to create a mess out of nothing. We will continue transaction-based historical costs rather than revaluing assets and liabilities by identifying their fair values."

The valuation problem has appeared to be more severe, however, for new accrual accounting adopters. The representatives of new adopters were aware of the fact that they are required to use marker/fair values for the recognition and measurement of their assets and liabilities once they accomplish their transition towards accruals. They were not however convinced that an active liquid market prevailed for many of their assets and that they were in a position to facilitate negotiate of their assets prices. During our informal talk, a Director General of the Treasury Bureau of one Asian country (a new adopter) mentioned how his 
country had adopted a rather different approach to assets valuation, claiming it was a lesson learned from the experience of early adopters. He further stated at the $10^{\text {th }}$ symposium:

"We are following two steps for the evaluation of our assets prior to their inclusion in the statement of financial position. First, we undertake a physical inspection of the assets and calculate their acquisition costs. Next, we assign the values to our assets after having analysed the inspection and the replacement costs calculated."

Several low and medium-intensity adopters raised concerns as to whether they should determine revenues and expenses by identifying inflows and outflows applicable to a particular period or by considering changes in net assets. The early adopters of accruals seemed, however, positive in using the fair value approach to their assets measurement. Unlike the medium and low-intensity accrual adopters, a challenge encountered by the early adopters was to elucidate to politicians and citizens the fluctuations which they might experience in the financial statements every year due to the changes in the value of assets. Their major concern had been to stop politicians taking advantage of such short-falls and wind-falls resulting from the changes in assets valuation, and using them to increase or cut expenditure on other social programmes.

The treatment of social insurance programmes has remained another contentious issue in most of the OECD member states, including the early adopters of public sector accruals. OECD (2002) states that there is a general consensus amongst the member states that contractual obligations such as government employees' pension programmes should be treated as a liability and incorporated in the statement of financial position. It has been argued that such programmes could be an enormous future obligation for the member states given the circumstances of an ageing population. However, we noticed that only a few member states had considered social insurance programmes a liability, in particular pensions. Given that pension plans had been funded on a pay-as-you-go basis in many countries, attendees representing the medium and low-intensity accrual adopters were of the view that there was no need to recognise such social insurance programmes as a liability and that these programmes could be adjusted in notes just for the sake of ensuring transparency.

Similarly, we noted an increasing trend of public private partnerships (PPPs) amongst countries in the OECD, not only to achieve improved value for money (VFM), but also to meet their fiscal targets (Demirag, Khadaroo, Stapleton, \& Stevenson, 2012; Demirag, 
Khadaroo, Stapleton, \& Stevenson, 2011). However, many OECD member countries have yet to recognise PPPs as part of their contingent liabilities and incorporate them in financial statements. The proponents of public sector accruals argue that the exclusion of PPPs in the financial statements would expose governments to the risk of unplanned debt at the expense of future generations (Araujo \& Sutherland, 2010). Discussions were held as to whether and to what extent the ongoing PPP projects in the member countries had been successful in terms of transferring risks, delivering value for money and providing cost savings. Elucidating the challenges with regard to the PPP projects, a Deputy Director for Budget at the Federal Financial Administration of a medium-intensity accrual adopter stated at the $10^{\text {th }}$ symposium:

"Different standards have imposed different requirements for the accounting of PPPs (see IFRIC 12, IPSAS 32, and Eurostat). We do not have standard guidance to define the PPP projects and identify the associated risks in our statements."

In addition to PPPs, the representatives of several OECD member states highlighted the challenges they had dealt with measuring and reporting of non-cash items (such as depreciation, impairment, scenarios and discounting rates). The treatment of non-cash items had seemingly led the member states to two kinds of difficulties, namely accuracy and volatility. This was evident in the following assertion made by a Chief Accounting Advisor at the Treasury of an early adopter at the $10^{\text {th }}$ symposium:

"Our biggest problem is to cope with the frequent changes in prices and costs and the impacts they have on forecasts, estimates, and appropriations. We are in a dilemma when calculating depreciations, selecting discounting rates and forecasting tax revenues."

On the whole, we have observed in the OECD that the accrual-based accounting has been accepted not only at the economic and political level, but also at the organisational-field and organisational levels (Dillard, Rigsby, \& Goodman, 2004; DiMaggio \& Powell, 1983). At the economic and political level, the European Commission and the OECD have envisaged the adoption of public sector accruals as a means through which to ensure the accountability and transparency of public sector entities in the light of the sovereign debt crisis (European Commission, 2012, 2013; Blöndal, 2003). Albeit not mentioned explicitly, these institutions have seemingly made the adoption of public sector accruals an institutional signal that may be regarded almost like an entry condition for their membership (see e.g. Ernst \& Young, 2012). This clearly indicates that many of the OECD member states are subject to coercive 
and normative pressures being exerted for the adoption of accrual accounting. There are also differences in the opinions of the actors with regard to accruals, depending upon the group of the country. While the treasury officers in early adopters are more concerned over elucidating the importance of accrual accounting to politicians and citizens, the majority of the budget officers, accountants and policy makers representing the low and medium-intensity adopters have given more emphasis to handling the political and technical ambiguities inherent to accrual accounting.

\subsection{Significance of accrual budgeting}

Accrual budgeting is defined as "the specification of budgetary expenditure authorisations and revenue estimates in terms of accrual accounting measures" (Robinson, 2009:4). Unlike the cash budget which is focused on the forecast and allocation of cash, accrual budget forecasts and demonstrates resources raised and consumed by the governments, and the manner in which obligations are incurred and settled. We have observed that discussions on various aspects of accrual budgeting and its implementation in the OECD member states were being held since the first annual OECD accrual accounting symposium. The fact that only three member states, i.e. Australia, New Zealand, and the UK have adopted full accruals for appropriations in the last decade clearly shows that there is far less acceptance of accruals for the budgeting purpose than for financial reporting (Blöndal, 2003, 2015; Bergmann, 2012; Schick, 2007). Six member states, i.e. Austria, Belgium, Denmark, Switzerland, Chile and Iceland, have in recent years introduced some degree of accruals in their appropriations, but they have excluded several important elements in the budget, for instance, the projection of public service pensions and the capitalisation of their assets (Blöndal, 2015). Such a lack of interest amongst member states to instigate accrual budgeting reforms is also evident in the bulk of academic work (Marti, 2006; Jones, Lande, Luder, \& Portal, 2013; Brusca, Montesinos, \& Chow, 2013).

As is the case in accrual accounting, there are both political and technical factors involved stifling the advancement of accruals for appropriations in the member states. The former however appears more dominating in the case of accrual budgeting. In most countries budgeting is not a system of forecasting, but a method to democratically decide on the authorisation to spend financial resources and to collect (mainly) taxes. Brusca, Montesinos, \& Chow (2013) mention that the budget has in many central European countries been central 
to their legal administrative culture. The legislators and politicians in many of these countries have envisaged accrual budgeting more as a caveat jeopardising the budget discipline and posing a substantial risk in the discharging of public accountability. They have had a view that only through cash budget would they be able to meet their parliamentary obligation, which is to demonstrate that the money they are allowed to spend matches the amounts reported in the budget. A Deputy Director of the State Budget Department at the Ministry of Finance of a medium-intensity accruals adopter remarked at the $8^{\text {th }}$ symposium:

"National budget and final accounts are also subject to parliamentary approval in our country. We have been preparing financial statements under [the] accrual basis of accounting voluntarily. We have however no intention to prepare accrual budgeting. Cash basis budgeting has advantages in terms of certainty, objectivity, and accessibility, of course if it is properly managed."

The fact that techniques such as accrual budgeting tend to weaken the legislature's control over the executive government means that the legislature should be ready to accept the shifts in the balance of power (Newberry, 2015; Jones, Lande, Luder, \& Portal, 2013). We observed that although the administrators in a number of low and medium-intensity adopters had positive opinions towards accrual budgeting, political support to accrual budgeting was rather weak. As is the case in accrual accounting, key actors at the organisational level primarily representing the low and medium-intensity adopters reiterated during the symposiums the view that the adoption of accrual budgeting would be easier in those countries in which the legislature has limited influence in the budget process. It has been argued that without the operational freedom to decide on the input mix for delivering public services, the adoption of accrual budging would be of little use in improving financial administration (Blöndal, 2003; USGAO, 2000). This was evident during our observation at the $10^{\text {th }}$ symposium. A Senior Advisor for the Ministry of Finance in a Scandinavian country (a medium-intensity adopter of accruals) stated:

"We know that a key element in accrual budgeting is to provide agencies [with] freedom in managing their expenditures. Our agencies are less controlled and we have provided them with an extended authority to incur their expenditures. Expenditure management is now more an element of management than a political issue in our country. We will have to wait and see whether this is a setback for parliamentarians." 
There are several cases in which the adoption of accrual budgeting has been dropped due to a lack of pressure being exerted by politicians at the organisational-field level. Norway and the Netherlands are two examples in this regard. In 2009, the Ministry of Finance, Netherlands, had undertaken comparative international research to unfold the international experience in accrual budgeting and accounting (see e.g. Brusca, Caperchione, Cohen, \& Rossi, 2015). Implicit in the findings of the research was that accrual budgeting could be a costly and time-consuming process and that the provision of information to the parliament could easily be improved without implementing accruals for line ministries. As a result, only agencies, which were business-like parts of the government, were considered suitable for the adoption of accrual accounting and budgeting. In a similar vein, Norway had appointed a commission to study the feasibility of accrual accounting and budgeting in 2007 (GårsethNesbakk, 2011). The commission members were in favour of giving continuity to the cash principle given that agencies were being regulated on the basis of inputs control.

In its report, the United States General Accounting Office (USGAO) (2000) states that there are views in many OECD member states that budgeting on a basis other than cash runs the risk of becoming a purely technical accounting exercise, which in turn, may demand a more sophisticated understanding of accounting standards and underlying assumptions. In fact, such technical ambiguities have appeared to be a factor which has led some member states to perceive accrual budgeting a part of rather than a complete solution in improving their public accountability. Representatives of a number of medium-intensity adopters have held a view that accrual budgeting could be a good mechanism for civil servants to enhance operational management by recognising the full cost of certain programmes. However, they are of the opinion that it could not be used for recognising longer-term fiscal challenges driven by factors such as an aging population and increasing health costs. The representatives of many member states (mainly from central Europe) alluded, during our observations, to how a range of benefits, for instance, improved asset registers, fiscal transparency and outcome measurement (to name just a few) could be achieved through accrual accounting and reporting, while keeping the appropriations on the cash basis. A Deputy Assistant Secretary of the Treasury Department of a medium-intensity adopter remarked at the $10^{\text {th }}$ symposium:

"We have continued to measure budget authority and outlays on a cash-and-obligation basis, except for some items such as credit programmes, certain interest payments, some federal employee pensions and some retiree health care. [A] cash budget with some accrual modifications can be a more pragmatic approach to us." 
When considering accrual budgeting the discussion is not anymore on how much money would be spent, but on how much costs (accruals) might be realised. Costs are allocated and charged and thus discussions about the allocation mechanisms arise, whereas in budget accounting, despite possible disagreements, the discussion is only about the money to be spent or collected. We observed that the majority of low and medium-intensity adopters were concerned over their capacity to allocate costs and to reap the perceived benefits of accrual budgeting as mentioned by its propagators (Blöndal, 2004). A Deputy Director General of the Budget Department representing a group of the low-intensity adopters commented at the $8^{\text {th }}$ symposium:

"For this change [accrual budgeting] to take place, we first need to train and educate our budget managers. We do not have appropriate valuation rules or IT infrastructure in place. We also need to change our focus, which is at the moment on improving the balance sheet and surplus. We are probably quite a way away from meeting the requirements of accrual budgeting."

Jones \& Lüder (2011) claim that a lack of absorptive capacity was evident amongst German federal governments, as many of them had to reverse their decision to consider accruals-based budgeting. Resolving the costs allocation issues and handling technical ambiguities inherited to accrual budgeting had been further complicated due to the absence of a standard procedures and guidance to prepare accrual budgeting. As is the case in accrual accounting, there is apparently no single way of doing accrual budgeting even amongst the high-intensity adopters. The USGAO (2000:19), for instance, shows the variations that countries have adopted in measuring the government-wide deficit/surplus in their accrual appropriations. While New Zealand reports its deficit/surplus using the accrual-based net operating results, Australia has introduced a "fiscal balance" measure by adjusting the accrual-based operating balance with the cash-and-other-national-investment-to-savings gap. Claims have also been made that the full costs, especially the long-term costs, have often been underestimated by the countries that had adopted accrual budgeting.

In a similar vein, there were issues with regard to the transparency of accrual budgeting over borrowing and debt management. A key dilemma that a number of low and mediumintensity adopters had faced was to set up expenses and expenditure limits for agencies and provide them with the authority to shift limits from one item to another; the problem envisaged was an increase in the total debt level resulting from such shifts. In addition, the 
member states were remained sceptical about the lack of the fiscal strategy in accrual budgeting. Commenting on his country's view on accrual budgeting at the $11^{\text {th }}$ symposium, a Public Account Officer representing the Ministry of Finance of a low-intensity adopter stated: "Accrual appropriations do not present the fiscal strategy. They just provide forecasts. For the government, such fiscal strategy communication is of the utmost importance for showing its priorities."

Standards setters, international organisations and professional accountants, i.e. the actors at the economic and political level (PwC, 2013; CIPFA, 2012), have however perceived accrual budgeting as an important component of broader public management reforms. Implicit in their assertions was that the adoption of accrual principles for reporting without similar use for budgeting would prevent countries reaping the advantages of accruals, and thereby improvements in their financial performance (see e.g. Ball, 2012; Blöndal, 2004). These organisations have presented accrual budgeting as a means through which to improve both operational management and external reporting. Accrual budgeting can be used internally for management support and undertaking effective management decisions, because it has the potential to link the total cost of resources being used to the performance achieved from those resources (USGAO, 2000). Such information is vital for the introduction of performance-focused management in the public sector. Similarly, mentions are made that accrual budgeting would help improve external reporting by delineating the longer-term implications of current decisions. The fact that it addresses annual changes in assets and liabilities means that public entities would be able to undertake better decisions with respect to the acquisition, disposal and maintenance of fixed assets (Robinson, 2009). In addition, they would have better incentives to identify and sell those non-financial assets that are reckoned to be non-beneficial by the incorporation of depreciation in the expense budget.

We observed during the symposiums that the high-intensity adopters had echoed similar supportive voices with regard to the importance and benefits of accrual budgeting in the public sector. Their countries were of the view that, for engendering the benefits of improved awareness of the financial impacts of their decisions, improved asset management, and improved risk assessment, the integration of the reporting with the budget process was a prerequisite. A Head of Government Internal Audit Profession at the Treasury of one highintensity accrual adopter expressed his view on accrual budgeting at the $10^{\text {th }}$ symposium: 
"We do not regret our decision to implement accrual budgeting along with financial reporting. If we were given a choice, we would do it again."

During our observations, we witnessed a clear division amongst the actors at organisational-field and organisational levels regarding the importance and applicability of accrual budgeting in their specific jurisdictions. The budget has remained a means of governance in many central European countries, and the politicians and legislators in these countries are seemingly not willing to facilitate changes in the budget system. The coercive pressures for the member countries to embrace accrual budgeting have therefore been weak (Carpenter and Feroz, 2001; DiMaggio and Powell, 1983). Indeed, some agencies and administrators of the low and medium-intensity adopters of accruals have supported accrual budgeting for internal purposes, i.e. operation management. Many of them, however, are yet to be convinced of the merits of its adoption as well as of their capacity to implement accrual budgeting for external reporting purposes. The early adopters of accruals are the main supporters and the carriers of accrual budgeting ideas. These countries, together with other propagators at the institutional level in particular the European Commission, the IFAC, and

professional accounting firms, have doubted the usefulness of accruals for financial reporting without its corresponding adoption for appropriations. The European Commission (2012) has mentioned that the proposed EPSASs would incorporate standards both for financial reporting and appropriations. It can therefore be argued that the institutional pressures being exerted on to the member states for the adoption for accrual budgeting may possibly strengthen in the future.

\subsection{The applicability of IPSASs}

The extent public sector accounting literature demonstrates that the IPSASs have failed to address the requirements of most of the central European and OECD governments in which public finance is centred around the annual budget (Benito, Brusca, \& Montesinos, 2007; Christiaens, Reyniers, \& Rolle, 2010; Pina \& Torres, 2003; Pina, Torres, \& Yetano, 2009). In many of these countries, the IPSASs are seen more as encompassing the Anglo-Saxon tradition of public sector accounting in which the financial statements are separated from the budgeting information and prepared to cater to the needs of the public in respect to large resource suppliers (Brusca, Montesinos, \& Chow, 2013). The fact that Australia, New Zealand and the UK have adopted IFRSs for their public sectors with certain amendments 
(i.e. a sector-neutral approach), and that their existing public sector accounting standards are considered closest to the IPSASs epitomises this. Ernst \& Young (2012), for instance, states that the UK accounting standards are more than 95\% compliant with the IPSASs.

We have noted during our observations that a number of EU and OECD member states, for instance, Italy and Slovakia, have expressed concerns over the lack of public-sectorspecific provisions in the IPSASs for recognising and measuring pension liabilities, social benefits, tax revenues and historical costs (see also Ernst \& Young, 2012; European Commission, 2012). The IPSASs are envisaged in these countries as too theoretical, complex, incomplete and costly approaches to streamlining their public sector accounting. In its assessment report, the European Commission (2012) has pointed out several critical issues relating to IPSASs, for instance, the governance of the IPSASB, the relationship between the IPSASs and the European Systems of Accounts and the 'left out of budgeting', amongst others, and clarified that the IPSASs cannot be implemented in EU member states as they currently stand. Using the IPSASs as a starting reference, the European Commission (2013) has made a recommendation for the development of a set of harmonised public sector accounting and budgeting standards, i.e. EPSASs. This trend towards the EPSASs has certainly become a caveat, warning not only against the suitability of the IPSASs but also against their future adoption by other EU and OECD member states. During our informal discussions at the $10^{\text {th }}$ symposium, a Budget Secretary of one medium-intensity adopter from North Europe remarked:

"We have critically reviewed all IPSASs in my country for seven years. They have the specific advantage of being an Anglo-Saxon approach and can be used for the programmes and projects of the IMF and other lenders/investors in developing nations. They could not meet the reporting requirements of Europe."

Prior studies on public sector accounting in emerging countries have delineated an increasing trend amongst these countries to adopt the IPSASs, as part of their attempt at mimicking best practices adopted by international organisations and Western countries (Adhikari, Kuruppu, \& Matilal, 2013; Harun, Peursem, \& Eggleton, 2012). We noticed during our observations that there was an absence of such mimetic pressure (DiMaggio \& Powell, 1983) being exerted to the OECD member states to instigate a step towards the IPSASs. A Senior Advisor at the Ministry of Finance of one Scandinavian country (a medium-intensity adopter) stated at the $10^{\text {th }}$ symposium: 
"For instance, Norway has not made the adoption of the IPSASs compulsory. Sweden adopted accrual accounting in an era prior to the IPSASs. Yes, we are encouraged to adopt and extend the use of accrual accounting but there is no such pressure/persuasion to adopt the IPSASs."

Representatives of several medium-intensity adopters and new accrual adopters were of the view that their annual reports in some ways corresponded to the IPSASs in terms of the basic principles and definitions of accounting elements being used. They raised several conflicting and technical issues during our informal talks however, which they claimed would be an impediment had they wished to fully converge with the IPSASs. A Treasury Head at the Ministry of Strategy and Finance of a new adopter commented at the $11^{\text {th }}$ symposium that his department amended several IPSASs, including employee benefits, financial instruments, borrowing costs and segment reporting, to eliminate alternatives available in the standards and reduce the complexity. Another senior budget officer representing a medium-intensity adopter from northern Europe mentioned the hesitation in his country to adopt the IPSASs by pointing to the asset-liability model implied in the standards, with an emphasis on fair value and market prices. The fact that his country had adhered to a revenue-expense model anchored on, amongst other things, historical costs, the prudence principle and the income sheet approach meant that the IPSASs were simply irrelevant. Illustrating the inapplicability of the IPSASs, the same budget officer commented at the $10^{\text {th }}$ symposium:

"IPSAS 19 does not provide any reason to alter the present valuation model of financial assets as stipulated in our budget decree."

In a similar vein, mention was also made by several participants about a lack of provision to address the main intangible asset inherent to government, i.e. the power to levy taxes. A number of participants, in particular from central European countries, were critical about the requirements as laid down in IPSASs 28-30 for financial instruments. There were also concerns over the inadequacy of the IPSASs in dealing with non-exchange transaction expenses, i.e. taxes and transfers, employee benefits, public debt and government revenues. For instance, non-exchange transaction expenses had been the main expense within their central governments and some other public entities; there were however no IPSASs available for those expenses. In addition, IPSAS 23 had turned out be irrelevant in many of these European governments given that their revenue sources had been very broad rather than defined in the standard. Similarly, IPSAS 29 appeared inapplicable in that many of these 
countries did not have a developed system that could separate commissions and expenses for their public debt.

We noticed during our observation that two key issues/requirements relating to the IPSASs, i.e. conceptual framework and whole government accounts (WGAs), had drawn the particular attention of the majority of the OECD member states. Having spent nine years and eight public consultations with the global constituency, the IPSASB has recently approved its "Conceptual Framework for General Purpose Financial Reporting by Public Sector Entities" (Christiaens \& Vandendriessche, 2015). The IPSASB claims that the framework has been developing by giving a special attention to specific public sector-related issues, and that it would provide a basis for preparing high-quality reports for both accountability and decision-making purposes. During our informal conversations at the $11^{\text {th }}$ symposium, the Chairman of the IPSASB remarked:

"The concept of accountability is very important in the public sector. Our objective is therefore not simply to interpret the IASB framework but to develop our own framework using the work of the IASB and others as appropriate. We have also considered several public sector-specific issues while developing the framework, for instance, involuntary transfers and non-exchange transactions, budget approval, the nature of public sector programmes, and the purpose of assets in the public sector."

However, evidence shows that the notion of government control used in the conceptual framework has proved problematic in a range of countries, including Australia, New Zealand and Spain, amongst others (Brusca \& Motesions, 2009). The accountability mechanisms in the public sector are primarily focused on the use of budget appropriations and on the services provided and effects achieved from the point of 'value for money'. This also means that the budgets statements and performance reporting, rather than the general purpose financial statements as prescribed in by the IPSASs, would continue to form a basis for discharging accountability in the public sector. Furthermore, questions have been raised about the way the users of financial statements have been identified in the conceptual framework. The citizens, resource providers, legislators, and other service recipients and their representatives have been reckoned to be the key users of the financial statements in the public sector, without any actual interviews or field work having been undertaken to specify their requirements and their varying information needs (Christiaens \& Vandendriessche, 2015). 
A major issue that the participants had raised, however, concerns the delay by the IPSAB in developing the framework. Views were expressed that the framework would have been introduced prior to the issuance of standards rather than when the standards are fully developed. Another related matter that we noted during the symposiums was the challenges that the members had encountered in identifying and defining accounting entities, a key requirement of the WGA. It is explicitly mentioned in IPSAS 6 that the consolidated financial statements should comprise all economic entities, i.e. controlling entities and any controlled entities. The challenge in identifying controlled entities has led many OECD and EU countries to exclude local governments, universities and state-controlled banks from their consolidated statements (Brusca \& Montesions, 2009). The WGAs of the UK central government perhaps serve as an illustration (Hyndman \& Connolly, 2011). The first audited WGA for the UK government, which was published for the fiscal year 2009-2010, aggregated the accounts of around 1,500 public entities. In its recent WGA for 2013-2014 published in March 2015, the UK Treasury has aggregated the accounts of 5,400 public entities (HM Treasury, 2015). Although the UK's WGAs are considered to be the world's largest consolidation exercise (Chow, Humphrey, \& Moll, 2009; Heald \& Geogriou, 2011), there are still many entities which may fall within the category of public entities, for instance, the Crown Estate, the Electoral Commission and the Independent Parliamentary Standards Authority, to name but a few, that are yet to have been brought under its scope.

What we noticed during our informal discussions with the representatives of OECD member states, however, was that the consolidated statements of some countries have eschewed not only certain public entities but also a number of important accounting items/transactions. A Senior Audit Director at the National Audit Office in a Scandinavian country (medium-intensity adopter) stated at the $8^{\text {th }}$ symposium:

"The central government uses the equity method for consolidation, but the IPSASs require a complete consolidation line by line. Not all units controlled by the government are therefore consolidated in the WGA. The central government does not consolidate the general pension funds either. There are no provisions for segment reporting."

As stated previously, although accrual accounting has been introduced in the majority of OECD member states, only a few countries have applied it to cover all sectors of the government, for instance, central government, local government and agencies. One reason for the exclusion of certain public entities in the consolidation has been the use of a variety of 
accounting policies and principles at different government levels. While the narrow scope of the WGA had been a key issue among medium and low-intensity adopters, the high-intensity adopters were more concerned over the issue of materiality in preparing the WGA. They were seemingly more focused on increasing the usefulness of the WGA by alienating intragovernment transactions and identifying the elements/issues that could potentially pose a threat to their public finance in the longer-term. A Senior Specialist at the Treasury of one high-intensity adopter commented at the $8^{\text {th }}$ symposium:

"We are asked by the public accounts committee to make better use of the WGA. We have given special attention to demonstrating the risks that our nuclear decommission and clinical negligence provisions, pension liabilities, long-term discount rates, and outstanding tax and tax written off may pose in the future while developing the WGA."

In the case of the IPSASs, we have noticed that the key actors at the macro level (i.e. the economic and political level) are to a large extent divided, which, in turn, has undermined the degree of pressures being exerted to the OECD member states for their adoption. The European Commission and the OECD are of the view that the IPSASs cannot be implemented in Europe in their present form, and are advancing a project to develop a separate set of accrual based standards (the EPSASs) for Europe. The fact that there are no institutional pressures being exerted onto the member states for the adoption of the IPSASs has raised concern over their applicability in OECD and EU member states. Prior studies have delineated how a lack of institutional pressures stifle the adoption and implementation of public sector accounting reforms (Carpenter \& Feroz, 2001; Hyndman \& Connolly, 2011; Pollanen \& Loiselle-Lapointe, 2012). This is evident in the following statement made by a Budget Officer of a medium-intensity adopter during our informal talks at the $11^{\text {th }}$ symposium:

"Unless we are faced with coercive pressure and legislation from the EU, no other force can compel us to adopt the IPSASs."

\section{Discussion and conclusions}

Drawing on the ideas of extended new-institutional theory, we have in this study sought to explore the major challenges involved in implementing public sector accruals in OECD member states. In particular, we have adopted the three-layer organisational structures of Dillard, Rigsby, \& Goodman (2004), and investigated the ways in which, and to what extent, 
the ideas and practices of accrual accounting, accrual budgeting and IPSASs have cascaded down from the OECD to member countries at the organisational-field level and then to public sector accountants, policy makers and budget officers (i.e. key actors at the organisational level) in individual member states. On top of our structural hierarchy, i.e. the economic and political level, there are organisations such the OECD, the European Commission, the IPSASB and the IMF. These organisations have evolved as dominant institutional players taking the role of regulators and experts in the field of public sector accounting. Together with the international accounting and auditing firms, they are involved in propagating to their members the importance and needs of public sector accruals.

We have noted that the views relating to accrual accounting, budgeting and IPSASs are divided among the member states. Not only are there variations among the member states in terms of adopting and implementing public sector accruals, which is also illustrated in the extant academic work and the reports of international organisations, standards setters and policy makers (IFAC, 2011; PwC, 2013; European Commission, 2012; Guthrie, Olson, \& Humphrey, 1999), there are differences in the ways the countries have perceived the importance of these reforms in their jurisdictions. In general, accrual accounting and reporting has been more accepted by the member states (i.e. at the organisational-field level), as compared to accrual budgeting and the IPSASs; and that the members are apparently convinced of the merits of accrual accounting and reporting to varying degrees and at some levels, if not at all government levels, i.e. central government, state and local government and social security funds (European Commission, 2012; Guthrie, Olson, \& Humphrey, 1999; Blöndal, 2003, 2004). This is illustrated by the fact that almost all member states, except perhaps Israel, Mexico, and Slovenia (see e.g. Blöndal, 2015), have either adopted some elements of accruals for reporting at their different government levels or are providing supplementary accruals information for statistics along with cash information (see Appendix B).

The support of accounting profession and firms, standards setters, and policy makers as actors at the economic and political level to accrual accounting envisages the normative pressures being exerted to the member states. Organisations such as the European Commission, the OECD and the IMF have given a particular attention to the financial positions of their member states in the evolving sovereign debt crisis. Reporting of balance sheet items such as liabilities and obligations that require substantial cash resources in the 
future (e.g. public sector pensions) have now become important for the member states (Ernst \& Young, 2012; European Commission, 2012). The ways in which accrual accounting is being promoted across the countries - not least in the OECD - as, for instance, a panacea of future financial crisis (see e.g. Ball, 2012) and a tool for high quality statistics (i.e. the GFS and the ESA) (see e.g. European Commission, 2012, 2013), certainly delineates the potency of coercive pressures, as shown in the extent institutional-based studies (Carpenter \& Feroz, 2001; Adhikari, Kuruppu, \& Matilal, 2013; Irvine, 2008; Ball \& Craig, 2010; Hyndman \& Connolly, 2011). Mimetic pressure has clearly become a driving force for the new adopters encouraging them to declare a big-bang approach towards public sector accruals (Ernst \& Young, 2012).

Our findings demonstrate that most if not all OECD member states have underestimated the complexity in implementing accrual accounting and therefore ended up spending more time, resources and effort on its adoption than originally planned. We argue that a rosy picture of accrual accounting has been presented to countries without giving much attention to its applicability at their organisational level. In propagating the benefits of accrual accounting, less attention has been paid on the competence and capacity of treasury and budget officers and policy makers, the key actors at the organisational level, who are actually involved in realising the propagated benefits of public sector accruals in their specific contexts. We have noted that many of these organisational actors, whether early or low and medium-intensity adopters, have been struggling to convince the citizens and to some extent the politicians of the importance of public sector accruals, and how the benefits of accrual accounting can overweigh the costs of pursuing cash accounting in an era of budget cuts. Challenges in elucidating the fluctuations to politicians, led by the changes in the assets values and estimations and preventing them to take advantages of such changes by prioritising or dropping other social programmes, have remained intact.

We have observed that several low and medium-intensity and new adopters have been exposed to a number of political and technical dilemmas in the process of implementing accrual accounting. Not only are the politicians particularly reticent to delegate their financial decision-making power to agencies, the budget and treasury officers in many of these countries are encountering technical ambiguities in areas such as assets valuation, identifying social insurance programmes, and recognising and reporting contingent liabilities and other non-cash items. The varied ways that these organisational actors have understood and 
addressed those contentious issues have led to further diversity in implementing accrual accounting. New adopters have even been forced to abandon their big-bang approach to reforms, putting more emphasis on the adoption of accrual accounting at the central level. As stated in prior-institutional-based work (Ezzamel, Hyndman, Johnsen, Lapsley, \& Pallot, 2007; Dillard, Rigsby, \& Goodman, 2004; Hyndman \& Connolly, 2011; Pollanen \& LoiselleLapointe, 2012), the adoption of accrual accounting in many of these countries (low and medium-intensity and new adopters) has seemingly been driven by their desire to cope with external/institutional pressure, and the interests and competence of organisational actors have often been marginalised and understated in the process.

The empirical evidence that we have presented clearly shows an increase in the institutional pressures being exerted onto the OECD member states for the adoption of accrual budgeting. Accrual budgeting is perhaps an area within public sector accruals in which the differences in the opinion of actors both at organisational-field and organisational levels are most striking. Only the early adopters are ostensibly convinced by the benefits of adopting full accrual budgeting as propagated by the European Commission, the IFAC and accounting firms (European Commission, 2012; PwC, 2013). The latter group is of the view that, without the subsequent adoption of accruals for appropriations, the benefits of accrual accounting would be negated in that the politicians would continue to give more attention to the budget. This increasing disintegration between accounting and budgeting has been envisaged as a cause of unintended consequences in public sector accruals. We argue that accrual budgeting requires more agreement from politicians and parliamentarians, i.e. decision-makers at the organisational-field level, than does accrual accounting, which is a system of recording not of decision-making. Given the key role of the budget in discharging accountability in many low-intensity adopters, mainly the central European countries, it is rather unrealistic to think that the politicians in these countries, who are hesitant even to delegate the required authorities to agencies for accrual reporting, would accept accrual budgeting, which requires them to abandon their power over financial decision-making (i.e. budget). Mention is made by budget and treasury officers in some medium-intensity adopters that accrual budgeting can be an effective tool for ascertaining costs of certain programmes. The adoption of full accruals for appropriations by recognising their longer-term fiscal challenges seems however to be beyond their needs and capacity. 
In a similar vein, we have demonstrated that the applicability of IPSASs has remained another contentious issue within public sector accruals. The key actors at the political and economic level have uttered divided positions undermining the potency of institutional pressures being exerted to the member states for the adoption of IPSASs. The fact that the early adopters have adhered to a sector-neutral approach, i.e. IFRSs with or without modifications at all levels (see e.g. Ryan, Guthrie, \& Day, 2007), implies that their accounting standards are relatively converged with the IPSASs, which have made trivial the issue of their adoption in their specific jurisdictions. Views shared by a number of low and medium-intensity adopters were that the IPSASs are meant for emerging nations given the lack of standards in these countries, and that most of the IPSASs are to be revised as to make them applicable in their jurisdictions. Ambiguities in defining entities and incorporating them in the WGA, and the issues such as governance of the IPSASB, a lack of conceptual framework and a proposal of EPSASs have all made the IPSASs less attractive among the budget and treasury officers in the low and medium-intensity adopters.

On the whole, we argue that the implementation of public sector accruals across countries, and the challenges that the countries have encountered in the process, have been much broader than outlined in the academic work and presented in the reports/studies of the proponents. All these political and technical ambiguities inherited to public sector accruals when cascaded down to the organisational level have brought about vast uncertainty and confusion amongst most of the budget and treasury officers who deal with public sector accruals in their specific jurisdictions, threatening the legitimacy at the organisational level. Our empirical findings bear witness to the key role held by the organisational actors, which extends far beyond discussions of organisational legitimacy (DiMaggio \& Powell, 1983) or decoupling (Meyer \& Rowan, 1977). Much of the new-institutionalism based work has oversimplified the inner work of organisations, effectively - albeit implicitly - treating them as well-functioning legitimacy machines (Dillard, Rigsby, \& Goodman, 2004). Making heard the voices of organisational actors, i.e. policy makers, accountants and budget officers of the OECD member states, with regard to the need and implementation of public sector accruals in their specific contexts, we have therefore contributed to this stream of literature. In addition, this insight also questions the important role of the macro factors heralded in recent publications (Pollanen \& Loiselle-Lapointe, 2012; Hyndman, Liguori, Meyer, Polzer, Rota, $\&$ Seiwald, 2014) regarding countries' accounting reforms. It has, for instance, been pointed out that a country's cultural climate, political orientation, economic performance and 
government size represent important determinants of a more accepting environment for accrual accounting. These factors could of course facilitate such an environment, but it seems overly simple to assume that the macro level factors could be vital factors in countries' reform implementations or compliance. This paper therefore calls for the need to establish more communication and cooperation amongst the actors at the economic and political, organisational-field and organisational levels to build a coherent body of knowledge in public sector accruals. This could make it easier to tackle the complexity of public sector accruals and develop solutions that are aligned with the specific context of the public sector. Such cooperation could also be a point of departure to public sector accounting harmonisation, an emerging notion in the public sector.

\section{References}

Adhikari, P., Kuruppu, C., \& Matilal, S. (2013). Dissemination and institutionalization of public sector accounting reforms in less developed countries: a comparative study of the Nepalese and Sri Lankan central governments. Accounting Forum, 37(3), 213-230.

Almquist, R., Grossi, G., van Helden, J., \& Reichard, C. (2013). Public sector governance and accountability. Critical Perspectives on Accounting, 24(7-8), 479-487.

Ahn, P., Jacobs, K., Lim, D.W., \& Moon, K. (2014). Beyond self-evident: recognising the problematic political context of accrual accounting adoption in South Korea. Financial Accountability \& Management, 30(1), 25-48.

Anessi-Pessina, E., \& Steccolini, I. (2007). Effect of budgetary and accruals accounting coexistence: evidence from Italian local government. Financial Accountability \& Management, 23(2), 113-131.

Araujo, S., \& Sutherland, D. (2010). Public-private partnerships and investment in infrastructure. OECD: Economics Department Working Paper No. 803.

Ball, I. (2012). New development: transparency in the public sector. Public Money \& Management, 32(1), 35-40.

Ball, A., \& Craig, R. (2010). Using neo-institutionalism to advance social and environmental accounting. Critical Perspectives on Accounting, 21(4), 283-293.

Ball, I., \& Pflugrath, G. (2012). Government accounting: Making Enron look good. World Economics, 13(1), 1-18.

Becker, S., Jagalla, T., \& Skærbæk, P. (2014). The translation of accrual accounting and budgeting and the reconfiguration of public sector accountants' identities. Critical Perspectives on Accounting, 25(4-5), 324-338. 
Benito, B., Brusca, I., \& Montesinos, V. (2007). The harmonization of government financial information systems: The role of the IPSASs. International Review of Administrative Sciences, 73(2), 293-317.

Bergmann, A. (2012). The influence of the nature of government accounting and reporting in decision-making: evidence from Switzerland. Public Money and Management, 32(1), 15-20. Blöndal, J. (2015). The OECD accruals survey. PowerPoint Presentation at the $15^{\text {th }}$ Annual OECD Accruals Symposium, 26 Feb, Paris. Available at (http://fr.slideshare.net/OECDGOV/d1-ams5-jon-blondal-oecd) (accessed December 30, 2015).

Blöndal, J. (2003). Accrual accounting and budgeting: key issues and recent development. OECD Journal on Budgeting, 3(1), 43-59.

Blöndal, J. (2004). Issues in accrual budgeting. OECD Journal on Budgeting, 5(4), 103-119.

Broadbent, J., \& Guthrie, J. (2008). Public sector to public services: 20 years of "contextual" accounting research. Accounting, Auditing \& Accountability Journal, 21(2), 129-169.

Brusca., Caperchione, E., Cohen, S,. \& Rossi, F. (2015). Public sector accounting and auditing in Europe: the challenge of harmonisation. Hampshire: Palgrave Macmillan.

Brusca, I., \& Montesinos, V. (2009). International experiences in whole of government financial reporting: lesson-drawing for Spain. Public Money \& Management, 29(9), 243-250.

Brusca, I., Montesinos, V., \& Chow, D. (2013). Legitimating International Public Sector Accounting Standards (IPSAS): the case of Spain. Public Money \& Management, 33(6), 437444.

Callon, M. (1986). The scallops of St. Brieuc Bay: some elements of a sociology of translation. In J. Law (Ed.), Power, action and belief (pp. 196-233). London: Routledge \& Kegan Paul.

Caperchione, E. (2006). The New Public Management - a Perspective for Finance Practitioners. Brussels: FEE.

Caperchione, E., Salvatori, F., \& Benghi, E. (2014). New development: where there's will, there's a way-acting beyond cutbacks. Public Money \& Management, 34(2), 135-138.

Carlin, T. (2005). Debating the impact of accrual accounting and reporting in the public sector. Financial Accountability \& Management, 21(3), 309-36.

Carruthers, B. (1995). Accounting, ambiguity, and the new institutionalism. Accounting, Organizations and Society, 20(4), 313-328.

Carpenter, V., \& Feroz, E. (2001). Institutional theory and accounting rule choice: An analysis of four US state governments' decisions to adopt generally accepted accounting principles. Accounting, Organizations and Society, 26(7/8), 565-596. 
Chartered Institute of Public Finance \& Accountancy (CIPFA). (2012). Assessment of the suitability of the International Public Sector Accounting Standards (IPSASs) for the member states: CIPFA's response. UK: CIPFA.

Chan, J. (2003). Government accounting: an assessment of theory, purposes and standards. Public Money \& Management, 23(1), 13-20.

Chua, W.F. (1995). Experts, networks and inscriptions in the fabrication of accounting images: a story of the representation of three public hospitals. Accounting, Organizations and Society, 20(2/3), 111-145.

Chow, D., Humphrey, C., \& Moll, J. (2009). New development: in pursuit of WGA- research findings from the UK. Public Money \& Management, 29(4), 257-260.

Christensen, M., \& Skærbæk, P. (2007). Framing and overflowing of public sector accountability innovations: a comparative study of reporting practices. Accounting, Auditing \& Accountability Journal, 20(1), 101-132.

Christensen, M., \& Skærbæk, P. (2010). Consultancy outputs and the purification of accounting technologies. Accounting, Organizations and Society, 35(5), 524-545.

Christiaens, J., Reyniers, B., \& Rolle, C. (2010). Impact of IPSAS on reforming governmental financial information systems: a comparative study. International Review of Administrative Sciences, 76(3), 537-554.

Christiaens. J., \& Vandendriessche, F. (2015). IPSASs conceptual framework: a comment. CIGAR Network Newsletter, 6(2), 2.

Christiaens, J., Vanhee, C., Manes-Ross, F., Aversano, N., \& Cauwenberge, P. (2014). The effects of IPSAS on reforming governmental financial reporting: an international comparison. International Review of Administrative Sciences, 8(1), 158-177.

Connolly, C., \& Hyndman, N. (2006). The actual implementation of accruals accounting caveats from a case within the UK public sector. Accounting, Auditing \& Accountability Journal, 19(2), 272-290.

Demirag, I., Khadaroo, I., Stapleton, P., \& Stevenson, C. (2012). The diffusion of risks of public private partnership contracts. Accounting, Auditing \& Accountability Journal, 25(8),1317-1339.

Demirag, I., Khadaroo, I., Stapleton, P., \& Stevenson, C. (2011). Risks and the financing of PPP: perspectives from the financiers. The British Accounting Review, 43(4), 294-310.

Dillard, J.F., Rigsby, J. T., \& Goodman, C. (2004). The making and remaking of organization context: Duality and the institutionalization process. Accounting, Auditing \& Accountability Journal, 17(4), 506-542. 
DiMaggio, P. J., \& Powell, W. W. (1983). The iron cage revisited: Institutional isomorphism and collective rationality in organizational fields. American Sociological Review, 48(2), 147160.

European Commission. (2013). Towards implementing European Public Sector Accounting Standards (EPSAS) for EU member states - public consultation on future EPSAS governance principles and structures. Public Consultation Paper. Brussels: EUROSTAT.

European Commission. (2012). Public consultation - assessment of the suitability of the International Public Sector Accounting Standards for the member states. Summary of responses. Brussels: EUROSTAT.

Ernst \& Young. (2012). Overview and comparison of public accounting and auditing practices in the 27 EU member states. UK.

Ezzamel, M., Hyndman, N., Johnsen, A., Lapsley, I., \& Pallot, J. (2007). Experiencing institutionalization: The development of new budgets in the UK devolved bodies. Accounting, Auditing \& Accountability Journal, 20(1), 11-40.

Ezzamel., M., Hyndman, N., Johnsen, A., \& Lapsley, I. (2014). Reforming central government accounting: an evaluation of an accounting innovation. Critical Perspectives on Accounting, 25 (4/5), 409-422.

Federation of European Accountants (FEE). (2007). Accrual accounting in the public sector. Brussels: FEE.

Goddard, A. (2010). Contemporary public sector accounting research-an international comparison of journal papers. The British Accounting Review, 42(2), 75-87.

Grossi, G., \& Soverchia, M. (2011). European Commission adoption of IPSAS to reform financial reporting. ABACUS, 47(4), 525-552.

Guthrie, G. (1998). Application of accrual accounting in the Australian public sector rhetoric or reality. Financial Accountability \& Management, 14(1), 1-19.

Guthrie, J., Olson, O., \& Humphrey, C. (1999). Debating developments in new public financial management: The limits of global theorising and some new ways forward. Financial Accountability \& Management, 15(3/4), 209-228.

Gårseth-Nesbakk, L. (2011). Accrual accounting representations in the public sector-A case of autopoiesis. Critical Perspectives on Accounting, 22(3), 247-258.

Heald, D., \& Geogriou, G. (2011). The macro-fiscal role of the U.K. Whole of Government Account. ABACUS, 47(4), 446-476.

Harun, H., Peursem, K., \& Eggleton, I. (2012). Institutionalization of accrual accounting in the Indonesian public sector. Journal of Accounting \& Organizational Change, 8(3),257-285. 
HM Treasury. (2015). Whole of government accounts: year ended 31 March 2014. UK.

Hood, C. (1995). The "new public management" in the 1980s: Variations on a theme. Accounting, Organizations and Society, 20(2/3), 93-109.

Hyndman, N., \& Connolly, C. (2011). Accruals accounting in the public sector: A road not always taken. Management Accounting Research, 22(1), 36-45.

Hyndman, N., Liguori, M., Meyer, R., Polzer, T., Rota, S., \& Seiwald, J. (2014). The translation and sedimentation of accounting reforms. A comparision of the UK, Austrian and Italian Experiences. Critical Perspectives on Accounting, 25(4-5), 388-408.

International Federation of Accountants (IFAC). (2011). Transition to the accrual basis of accounting: guidance for public sector entities. Study 14 ( $3^{\text {rd }}$ ed.). New York: IFAC.

International Monetary Fund (IMF). (2003). International task force on harmonisation of public sector accounting, Minutes of the steering group meetings. Paris: OECD Headquarters.

International Monetary Fund (IMF). (2009). Transition to accrual accounting. Washington: IMF.

Irvine, H. (2008). The global institutionalization of financial reporting: The case of the United Arab Emirates, Accounting Forum, 32(2), 125-142.

International Public Sector Accounting Standards Board (IPSASB). (2014). The future governance of the International Public Sector Accounting Standards Board (IPSASB). IFAC. Jagalla, T., Becker, S., \& Weber, J. (2011). A taxonomy of the perceived benefits of accrual accounting and budgeting: evidence from German states. Financial Accountability \& Management, 27(2), 134-165.

Jacobs, K. (2012). Making sense of social practice: Theoretical pluralism in public sector accounting research. Financial Accountability \& Management, 28(1), 1-25.

Jones, R., Lande, E., Lüder, K., \& Portal, M. (2013). A comparison of budgeting and accounting reforms in the national governments of France, Germany, the UK and the US. Financial Accountability \& Management, 29(4), 419-441.

Jones, R., \& Lüder, K. (2011). The federal government of Germany's circumspection concerning accrual budgeting and accounting. Public Money and Management, 31(4),26570 .

Justensen L., \& Mouritsen, J. (2011). Effects of actor-network theory in accounting research. Accounting, Auditing \& Accountability Journal, 24 (2), 161-193. 
Lapsley, I., Mussari, R., \& Paulsson, G. (2009). On the adoption of accrual accounting in the public sector: A self-evident and problematic reform. European Accounting Review, 18(4), 719-723.

Latour, B. (1987). Science in Action: How to Follow Scientists and Engineers Through Society. Cambridge, MA: Harvard University Press.

Likierman, A. (2003). Planning and controlling UK public expenditure on a resource basis. Public Money and Management, 23(1), 45-50.

Lombrano, A., \& Zanin, L. (2013). IPSAS and local government consolidated financial statements - proposal for a territorial consolidated method. Public Money \& Management, 33(6), 429-436.

Lüder, K., \& Jones, R. (2003). Reforming Governmental Accounting and Budgeting in Europe. Fachverlag Moderne Wirtschaft.

Lukka, K,. \& Vinnari, E. (2014). Domain theory and method theory in management accounting research. Accounting, Auditing \& Accountability Journal, 27(8), 1308-1338.

Lowe, A. (2000). The construction of a network at Health Waikato: the towards clinical budgeting project. Accounting, Auditing \& Accountability Journal, 13(1), 84-114.

Marti, C. (2006). Accrual budgeting: accounting treatment of key public sector items and implications for fiscal policy. Public Budgeting \& Finance, 26(2), 45-65.

Mellett, H. (2002). The consequences and causes of resource accounting. Critical Perspectives on Accounting, 13(2), 231-254.

Meyer, J., \& Rowan, B. (1977). Institutional organizations: Formal structures as myth and ceremony. American Journal of Sociology, 83(2), 340-363.

Modell, S. (2013). Making sense of social practice: theoretical pluralism in public sector accounting research: a comment. Financial Accountability and Management, 29(1), 99-110.

Monsen, N. (2002). The case for cameral accounting. Financial Accountability \& Management, 18(1), 39-72.

Monsen, N. (2008). Governmental accounting in Norway: a discussion with implications for international development. Financial Accountability \& Management, 24(2), 151-167.

Newberry, S. (2015). Public sector reforms and sovereign debt management: capital market development as strategy? Critical Perspectives on Accounting, 27 (March), 101-117.

OECD. (2013). The OECD Accruals Survey. Presentation at the $13^{\text {th }}$ Annual OECD Accruals Symposium. Available at

http://www.oecd.org/gov/budgeting/13thannualoecdpublicsectoraccrualssymposiumparis7-

8march2013.htm) (accessed December 30, 2015). 
Oulasvirta. L. (2014). The reluctance of a developed country to choose International Public Sector Accounting Standards of the IFAC. A critical case study. Critical Perspectives on Accounting, 25(3), 272-285.

Pina, V., \& Torres, L. (2003). Reshaping public sector accounting: An international comparative view. Canadian Journal of Administrative Sciences, 20(4), 334-50.

Pina, V., Torres, L., \& Yetano, A. (2009). Accrual accounting in EU local governments: One method, several approaches. European Accounting Review, 18(4), 765-807.

Pollanen, R., \& Loiselle-Lapointe, K. (2012). Accounting reform in the government of Canada: Exploratory evidence on accrual accounting adoption and impact. Financial Accountability \& Management, 28(4), 359-377.

Portal, M., Lande, E, Jones, R., \& Luder, K. (2012). French revolution and German circumspection: reforming budgeting and accounting in national governments. Public Money \& Management, 32(5), 323-392.

Preston., A., Cooper, D., \& Coombs, R.W. (1992). Fabricating budgets: a study of the production of management budgeting in the National Health Service. Accounting, Organizations and Society, 31(6), 559-578.

PWC. (2013). Towards a new era in government accounting and reporting. PWC:

PwC Global survey on accounting and reporting by central governments.

Robinson, M. (2009). Accrual budgeting and fiscal policy. IMF working paper (WP/09/84). IMF: Fiscal Affairs Department.

Ryan, C., Guthrie, G., \& Day, R. (2007). Politics of financial reporting and the consequences for the public sector. ABACUS, 43(4), 474-487.

Schick, A. (2007). Performance budgeting and accrual budgeting: decision rules or analytical tools. OECD Journal of Budgeting, 7(2), 109-137.

Tsamenyi, M., Cullen, J., \& Gonzalez, J. S. G. (2006). Changes in accounting and financial information system in a Spanish electricity company: A new institutional theory analysis. Management Accounting Research, 17(4), 409-432.

United States General Accounting Office (USGAO). (2000). Accrual budgeting: experiences of other nations and implications for the United States. Unites States General Accounting Office.

U.S. Department of the Treasury. (2010). Citizen's Guide to the fiscal year. USA: The Bureau of Fiscal Service.

U.S. Department of the Treasury. (2014). Citizen's Guide to the fiscal year. USA: The Bureau of Fiscal Service. 
Van Helden, J., Johnsen, A., \& Vakkuri, J. (2008). Distinctive research patterns on public sector management accounting research. Financial Accountability \& Management, 26(2), 213-240.

\section{Further references}

OECD Public Sector Accruals: Available at (http://www.oecd.org/gov/budgeting/accrualsaccrualaccountingaccrualbudgeting.htm) (accessed December 30, 2015)

OECD Senior Budget Officials network on financial management (for presentation slides and documents): Available at

(http://www.oecd.org/gov/budgeting/seniorbudgetofficialsnetworkonfinancialmanagement.ht m) (accessed December 30, 2015) 


\section{Appendix A}

List of OECD countries and the date of their membership (see e.g.

http://www.oecd.org/about/membersandpartners/list-oecd-member-countries.htm

AUSTRALIA

AUSTRIA

BELGIUM

CANADA

CHILE

CZECH REPUBLIC

DENMARK

ESTONIA

FINLAND

FRANCE

GERMANY

GREECE

HUNGARY

ICELAND

IRELAND

ISRAEL

ITALY

JAPAN

KOREA

LUXEMBOURG

MEXICO

NETHERLANDS

NEW ZEALAND

NORWAY

POLAND

PORTUGAL

SLOVAK REPUBLIC

SLOVENIA

SPAIN

SWEDEN

SWITZERLAND

TURKEY

UNITED KINGDOM

UNITED STATES
7 June 1971

29 September 1961

13 September 1961

10 April 1961

7 May 2010

21 December 1995

30 May 1961

9 December 2010

28 January 1969

7 August 1961

27 September 1961

27 September 1961

7 May 1996

5 June 1961

17 August 1961

7 September 2010

29 March 1962

28 April 1964

12 December 1996

7 December 1961

18 May 1994

13 November 1961

29 May 1973

4 July 1961

22 November 1996

4 August 1961

14 December 2000

21 July 2010

3 August 1961

28 September 1961

28 September 1961

2 August 1961

2 May 1961

12 April 1961 


\section{Appendix B}

Public sector accruals in the OECD member states (see e.g. Blöndal, 2015)

\begin{tabular}{|c|c|c|}
\hline Groups & Countries & Descriptions \\
\hline $\begin{array}{l}\text { High- } \\
\text { intensity } \\
\text { adopters }\end{array}$ & $\begin{array}{l}\text { Australia } \\
\text { New Zealand } \\
\text { UK }\end{array}$ & $\begin{array}{l}\text { Full accruals } \\
\text { for financial } \\
\text { statements and } \\
\text { budgets }\end{array}$ \\
\hline $\begin{array}{l}\text { Medium- } \\
\text { intensity } \\
\text { adopters }\end{array}$ & $\begin{array}{l}\text { Austria (financial reporting and budget) } \\
\text { Belgium (financial reporting and budget) } \\
\text { Canada (financial reporting) } \\
\text { Chile (financial reporting and budget) } \\
\text { Czech (financial reporting) } \\
\text { Denmark (financial reporting and budget) } \\
\text { Estonia ( financial reporting and transitioning to accrual budget) } \\
\text { Finland (financial reporting and some appropriations on accruals) } \\
\text { France (financial reporting) } \\
\text { Hungary (financial reporting) } \\
\text { Iceland (financial reporting and budget) } \\
\text { Latvia (financial reporting) } \\
\text { Lithuania (financial reporting) } \\
\text { Korea (financial reporting) } \\
\text { Poland (financial reporting) } \\
\text { Slovak republic (financial reporting) } \\
\text { Spain (financial reporting) } \\
\text { Sweden (financial reporting and running costs on accruals) } \\
\text { Switzerland (financial reporting and budget) } \\
\text { Turkey (financial reporting) } \\
\text { United States (financial reporting and loan and guarantee programs on accruals) }\end{array}$ & $\begin{array}{l}\text { Some elements } \\
\text { of accruals at } \\
\text { their central } \\
\text { government } \\
\text { levels either for } \\
\text { reporting and } \\
\text { budgeting or in } \\
\text { both. }\end{array}$ \\
\hline $\begin{array}{l}\text { Low- } \\
\text { intensity } \\
\text { adopters }\end{array}$ & $\begin{array}{l}\text { Germany } \\
\text { Greece (supplementary accrual information is provide for ESA 95) } \\
\text { Ireland (supplementary accrual information is provide) } \\
\text { Israel } \\
\text { Italy (supplementary accrual information is provide) } \\
\text { Japan (full accruals statements are also prepared although the cash is the legal } \\
\text { basis) } \\
\text { Luxembourg (supplementary accrual information is provide for ESA 95) } \\
\text { Mexico } \\
\text { Netherlands (agency reporting on accruals) } \\
\text { Norway (supplementary accrual information is provide) } \\
\text { Portugal (agency reporting on accruals) } \\
\text { Slovenia }\end{array}$ & $\begin{array}{l}\text { Follow the } \\
\text { cash basis at } \\
\text { the central } \\
\text { level (few of } \\
\text { them however } \\
\text { provide } \\
\text { supplementary } \\
\text { accrual } \\
\text { accounting } \\
\text { information) }\end{array}$ \\
\hline $\begin{array}{l}\text { New } \\
\text { adopters } \\
\text { (non- } \\
\text { members) }\end{array}$ & $\begin{array}{l}\text { Brazil (transition to accrual accounting) } \\
\text { China (transition to accrual accounting) } \\
\text { South Africa (transition to IPSASs) }\end{array}$ & \\
\hline
\end{tabular}

